\title{
KENDALA YANG DI HADAPI DALAM PANDEMI COVID-19 PADA PENGIRIMAN BAHAN POKOK (SUPPLY CHAIN) DARI PULAU JAWA KE WILAYAH INDONESIA BAGIAN TIMUR
}

\author{
Sutini \\ Universitas Maritim AMNI Semarang \\ e-mail :paleon_sutini@yahoo.co.id
}

\begin{abstract}
ABSTRAK
Sejak Otoritas Cina mengkonfirmasi bahwa mereka telah mengidentifikasi sebuah virus baru yang bernama novel coronavirus (2019-nCoV) pada tanggal 7 Januari 2020. Dampak virus ini tidak hanya pada kesehatan saja, tetapi juga dampak terhadap finansial dan sosial secara keseluruhan. Tol laut adalah konsep memperbaiki pengangkutan yang ada di Indonesia. Diharapkan Indonesia dapat meningkatkan proses distribusi yang ada dalam bahan pangan maupun bahan pokok, sehingga dapat mempermudah pemerataan bahan pokok di pulau jawa maupun ke luar pulau jawa,untuk menekan biaya yang terlampau berbeda jauh dari pulau jawa hingga luar pulau jawa. Upaya dari pemerintah untuk meningkatkan konektivitas antar pulau di Indonesia sehinga terwujudnya kesejahetraan di Indonesia. Melalui pembangunan Tol Laut dalam RPJMN 2014-2019. Tujuan dari Tol Laut ini adalah menurunkan disparitas harga barang dan pemerataan pembangunan ekonomi antara Kawasan Indonesia Barat dan Timur. Permaslahan dalam penelitian adalah Pentingnya suply chain dalam pengiriman barang, Peran pelabuhan dalam pengiriman barang sampai ketujuan dan Terhambatnya pengiriman barang melalui jasa pelayaran dapak dari covid 19. Metode penelitian yang digunakan adalah Metode kualitatif dengan objek riset pada Pelabuhan Banyuwangi.
\end{abstract}

Kata kunci : Konektivitas maritim, Distribusi logistik.

\begin{abstract}
Since the Chinese authorities confirmed that they had identified a new virus called novel coronavirus (2019-nCoV) on January 7, 2020. The impact of this virus is not only on health, but also on financial and social impacts as a whole.T he sea highway is the concept of improving existing transportation in Indonesia. It is hoped that in Indonesia it can improve the distribution process in Indonesia and increase in food and staple goods. It is hoped that it can facilitate the distribution of staple goods from Java to outside Java, to reduce costs that are too different from Java to outside Java. The government's efforts to improve connectivity between islands in Indonesia so that the realization of prosperity in Indonesia. Through the construction of the Sea Highway in the RPJMN2014-2019. The purpose of this Sea Highway is to reduce the disparity in the price of goods and equal distributioneconomic development between the West and East Indonesia Regions. The problems in the research are 1. The importance of supply chain to the delivery of goods 2 . The role of the port in sending goods to their destination 3. Inhibition of delivery of goods through shipping services dapak from Covid 19. The research method used is a qualitative method with the object of research at the Port of Banyuwangi.
\end{abstract}

Keywords: Maritime connectivity, Logistics distribution. 


\section{Pendahuluan}

Perekonomian jelas terpukul akibat adanya pandemi yang ada saat ini. Bisnis logistik misalnya adalah contoh paling mudah yang bisa terbayang sehancur-hacurnya apa lagi setelah meledaknya kasus COVID-19 di dunia. Hal ini berdampak sangat dengan sektor logistik yang berada sangat dekat terhadap dampak virus corona. Serangan wabah corona (COVID-19) memasuki babak baru. World Health Organization (WHO) sudah mengumumkannya sebagai pandemi global. Tak hayal negeri sebesar Tiongkok merupakan global production di era perekonomian saat ini. Lumpuhnya sebagian besar ekonomi Tiongkok menyebabkan rantai pasok ke para mitra dagangnya terganggu, termasuk Indonesia. Efeknya menjalar tanpa mengenal batas negara. Dalam situasi serba tidak pasti untuk perekenomian ini, pelaku logistik harus memutar otak menemukan solusi agar tetap bertahan. Logistik mengupayakan terus menambah shipper dan transporter. Hal ini perlu untuk menambal sepinya permintaan truk yang mendistribusikan cargo atau barang mereka. Adanya lonjakan permintaan pengiriman barang di tengah kekawatiran dan kewaspadaan masyarakat dalam infeksi virus Corona yang menyebabkan COVID-19. pentingnya supply chain pada pegiriman barang yaitu dapat terkontrolnya barang yang dikirim dan dibongkar pada pelabuhan maka supply chain menjadi kunci penting dalam jasa logistik kapal,

Meski terjadi kenaikan permintaan jasa logistik, terutama sejak pemerintah mengeluarkan imbauan bekerja dari rumah atau work from home, banyak masalah yang timbul akibat work from home terutama dalam pengiriman logistik yang sangan membuat batasan dalam pergerakan pengiriman barang terutama di Indonesia yang pengiriman barang dari pulau jawa ke Indonesia bagian timur. Pandemi COVID-19 telah berdampak pada berbagai sektor, apalagi dalam pendistribusian barang, akses logistik pangan makin parah di tengah makin meluasnya aksi karantina wilayah (Anjar Priyono, 2008). Bila kesulitan bahan pangan, bahanyanya tentu akan terjadi chaos atau kerusuhan masal. "Bukan tidak mungkin distribusi pangan disana terganggu karena tenaga kerja yang tersedia sedikit. Ada cara yang bisa dilakukan untuk mengatasi itu. Salah satunya adalah memaksimalkan peran transportasi daring. Selain itu, tentu saja diupayakan tenaga tambahan dan pemberian intensif bagi mereka yang terlibat dalam proses pengiriman barang. Insentif bisa berupa subsidi biaya pengiriman. Indonesia dapat menangani hal tersebut dengan cara memperbaiki di sektor maritime dalam infrastruktur pelabuhanya guna menunjang proses bongkar muat dan mendukung program yang di canamkan oleh presiden Joko Widodo (Elfrida R Gultom, 2017).

Dalam rangka pelaksanaan program tol laut ini tertuang dalam Peraturan Presiden Nomor 106 Tahun 2015 tentang Penyelenggaraan Kewajiban Pelayanan Publik untuk Angkutan Barang Dalam Rangka Pelaksanaan Tol Laut yang diikuti dengan terbitnya Peraturan Menteri Perhubungan Nomor PM. 161 Tahun 2015 tanggal 16 Oktober 2015 tentang Penyelenggaraan Kewajiban Pelayanan Publik untuk Angkutan Barang di Laut dan Peraturan Menteri Perhubungan Nomor 168 Tahun 2015 tentang Tarif Angkutan Barang Dalam Negeri dan Bongkar Muat Dalam Rangka Pelaksanaan Tol Laut ini dapat memberi angin segar pada masa pandemi ini karena dapat menjadi solusi yang tepat pada masa pandemi, namun sayang corona ini mengacaukan segala sektor baik ekonomi maupun sistem logistik baik itu pada masa pandemi sedang terjadinya dan meledaknya pandemi ini dan setelah menurunya wabah corona.

Tujuan dari penelitian ini adalah menangani kendala yang di hadapi dalam supply chain atau pengiriman barang dalam pandemi COVID-19 dari pulau jawa ke luar jawa/Indonesia bagian timur dengan berbagai masalah yang mucul dalam pandemi ini maka tujuan penelitian ini membahas tantang kendala yang di hadapi dalam pandemi yang terjadi di seluruh dunia dan berdampak pada Indonesia dengan menjabarkan dan menjelaskan tentang peranan pelabuhan dalam pengiriman barang yang di lakukan pada masa pandemi ini apakah dengan adanya virus COVID-19 ini berdampak pada terlambatnya atau terhambatnya pengiriman barang melalui jalur laut dengan moda rasnportasi kapal dan juga imbas yang terjadi sebelum COVID-19 ini pada masa sebelum covid sedang mewabahnya virus corona ini dan sesuda terjadinya virus ini akankah berdampak pada pelayaran dan negara. Sedangkan manfaat Penelitian yang diharapkan peneliti adalah memberikan solusi terhadap masyarakat yang mengalami dapak pandemi COVID-19 dari sektor ekonomi.

\section{Metode Penelitian}


Pengambilan data penelitian dilaksanakan dengan observasi langsung di pelabuhan Banyuwangi sebagai penyalur barang di wilayah Indonesia bagian Timur, dengan mewawancarai Kepala Pelabuhan Banyuwangi perihal distribusi penyaluran barang yang ada di pelabuhan Banyuwangi. Sedangkan jenis data yang digunakan adalah jenis penelitian kualitatif dimana jenis penelitian ini merupakan penelitian yang temuan-temuannya tidak diperoleh melalui prosedur statistik atau bentuk hitungan lainnya (Sugiyono, 2006). Metode kualitatif yaitu pengamatan, wawancara atau penelaahan dokumen. Jenis pelaporan menggunakan analisis deskriptif yaitu laporan penelitian yang berisi kutipan kutipan data untuk memberikan gambaran penyajian laporan tersebut.

Sedangkan metode analisis yang digunakan adalah metode analisis deskriptif yaitu metode yang ditunjukkan untuk mendeskripsikan atau menggambarkan fenomena yang ada, baik fenomena yang bersifat ilmiah ataupun rekayasa manusia. Penelitian ini mengkaji bentuk, aktivitas, karakteriskan, perubahan, hubungan, kesamaan dan perbedaannya dengan fenomena lain (Sugiyono, 2006). Penelitian ini bersifat deskriptif yaitu penelitian yang memberikan data tentang suatu keadaan atau gejala-gejala sosial yang berkembang ditengah-tengah masyarakat sehingga dengan adanya penelitian ini diharapkan dapat memperoleh gambaran yang menyeluruh, lengkap dan sistematis tentang objek yang akan diteliti.

1. Tahap Identifikasi Permasalahan

Tahap ini merupakan awal lahirnya ide penelitian ini, dimana pada tahap ini terdapat fakta-fakta dan permasalahan yang terjadi pada kondisi saat ini. Dengan dibantu data pendukung yang ada baik data primer maupun data sekunder atau juga data survey di pelabuhan Banyuwangi yang akan diteliti untuk menyelesaikan permasalahan tersebut.

2. Tahap Tinjauan Pustaka dan Studi Literatur

Pada tahap ini dilakukan studi literatur yang terkait dengan permasalahan pada penelitian ini, materi-materi yang digunakan sebagai tinjauan pustaka adalah kendala yang di hadapi dalam pengiriman barang pada masa COVID-19, dampak akibat dari COVID-19 dalam pengiriman barang, jenis peti kemas, jenis kapal yang digunakan untuk mengangkut peti kemas.

3. Tahap Pengumpulan Data

Metode pengumpulan data dalam penelitian adalah metode pegumpulan data secara langsung dan tidak langsung, data ini dilakukan dengan mengambil data pada pelabuhan Banyuwangi dengan permasalahan dalam pengiriman barang dalam masa covid-19 ini. Adapun data data yang diperlukan antara lain adalah:

a. Data mengenai data kapal yang masuk dan keluar pada pelabuhan .

b. Data ukuran dan berat dari kapal yang masuk pada pelabuhan .

c. Letak dari geografis pelabuhan

d. Pengenmabangan wilayah di sekitar pelabuhan

e. Data tentang peti kemas.

\section{Pembahasan}

Dalam Pembahasan ini terdapat dua poin pembahasan yaitu mengenai pembuatan peti kemas lipat khusus sapi dan bagaimana pola pengoperasian peti kemas lipat khusus sapi dari sentra produsen menuju sentra konsumenyang di fungsikan untuk efektifitas pengiriman bahan pokok di Pelabuhan, khususnya Pelabuhan Banyuwangi. Untuk proses pembuatan peti kemas lipat khusus sapi ini terdiri dari bahan-bahan/material yang diperlukan untuk membuat peti kemas lipat khusus sapi, bagaimana desain peti kemas lipat khusus sapi itu sendiri dan analisis biaya perbandingan jika pengangkutan menggunakan peti kemas lipat khusus dibandingkan dengan pengangkutan kondisi eksisting. Untuk pola operasi peti kemas hewan ternak terdiri dari skenario-skenario pengangkutan baik dari jalur darat maupun jalur laut beserta moda transportasi yang digunakan dari sentra produsen ke sentra konsumen dan biaya-biaya yang dilakukan untuk menjalankan skenario-skenario pengangkutan tersebut

a. Pelabuhan Banyuwangi

Pelabuhan Banyuwangi yang berada di Banyuwangi menunjukan bahwa pelabuhan tersebut berpotensi sebagai pelabuhan yang tepat untuk prancanaan tol laut dengan mempertimbangkan kedalaman yg dimiliki 12 meter sampai dengan 14 meter dari dasar laut menunjukan potensinya yang besar bila pemerintah ingin membangun dan mengembangkan pelabuhan 
tanjung wangi sebagai pelabuhan besar.

b. Faktor Terhambatnya Pengiriman barang melalui Jasa Pelayaran Dampak Dari COVID-19

Adanya faktor pembatasan pelabuhan upaya dalam pencegahan penagangan virus corona,peningkatan biaya yang terjadi pada penyaluran barang logistik di karenakan adanya screening di pelabuhan tujuan yang memperpanjang waktu pelayaran maka dari itu pengiriman barang terhambat dari pelabuhan asal yang mana menunggu proses kesehatan dan pengecekan yang membutuhkan waktu yang lama, dan sebelum masuk kepalabuhan tujuan karena guna menanggulangi COVID-19 menyebar melalui claster pengiriman barang.

c. Dampak Pada Sektor Ekonomi Sebelum COVID-19, Dan Dalam Kendala Covid-19, Di Masa Norma Baru Pada Pandemi COVID-19

Dampak dari pandemi COVID-19 dapat terlihat dalam keluar masuknya kapal yang ada di pelabuhan Banyuwangi dimana pada bulan january hingga february masih seperti biasa hanya memasuki bulan maret mulai ada penurunan dalam kapal yang datang dan keluar dari pelabuhan dikarenakan adanya perarturan pencegahan penanggulangan penyakit yaitu COVID-19, banyak kapal yang menaggur karna rantai pasok atau supply chain mengalami kendala yaitu kendala pada penyaluran barang yang ada didarat.dan data tersebut diambil dari data kegiatan operasional pelabuhan banyuwangi tahun 2020 disajikan oleh KSOP Kelas III Banyuwangi.

d. Data Kapal Bulan Januari Hingga Agustus

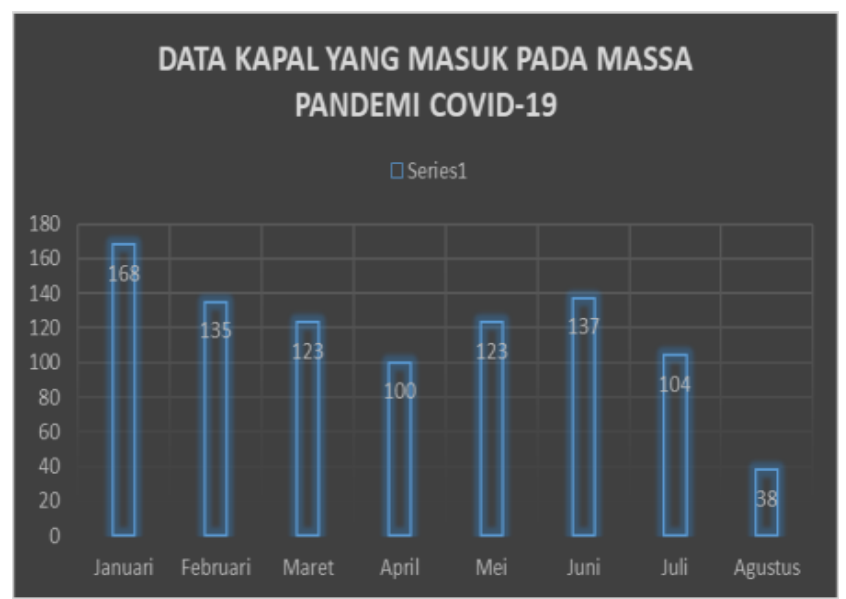

Gambar 1. Data Kapal yang Masuk pada Massa Pandemi Covid-19

(Sumber : Data Primer penelitian)

Terjadinya penurunan yang signifikan pada kapal yang bersandar di pelabuhan Banyuwangi akibat adanya pembatasan pelabuhan agar memutus rantai dari COVID19 maka dari itu terjadi penurunan yang terlihat dalam data yang di tunjukan dalam tabel.data ini juga di dukung oleh data bongkar muat yang biasa dilakukan di pelabuhan tanjungwangi data ini diambil dan dikomulatif menjadi tabel grafik yang menunjukan presentasi muatan yang biasa dibongkar dan dimuat pada pelabuhan tanjung wangi.

e. Pada Bulan Januari Pelabuhan Tanjung Wangi Data Pembongkaran Muatan

Analisa dari data grafik diatas dapat ditarik kesimpulan bahwa barang logistik yang sering masuk dan keluar pada pelabuhan tanjung wangi adalah barang barang kebutuhan sehari hari namun mengacu pada bahan bakar, barang campuran, bahan kelontong, pupuk, dan ikan beku. Dari bulan januari hingga februari masih stabil namun pengiriman barang pada bulan maret hingga bulan agustus mengalami penurunan, dimana penurunan ini diakibatkan oleh pandemi yang ada saat ini.

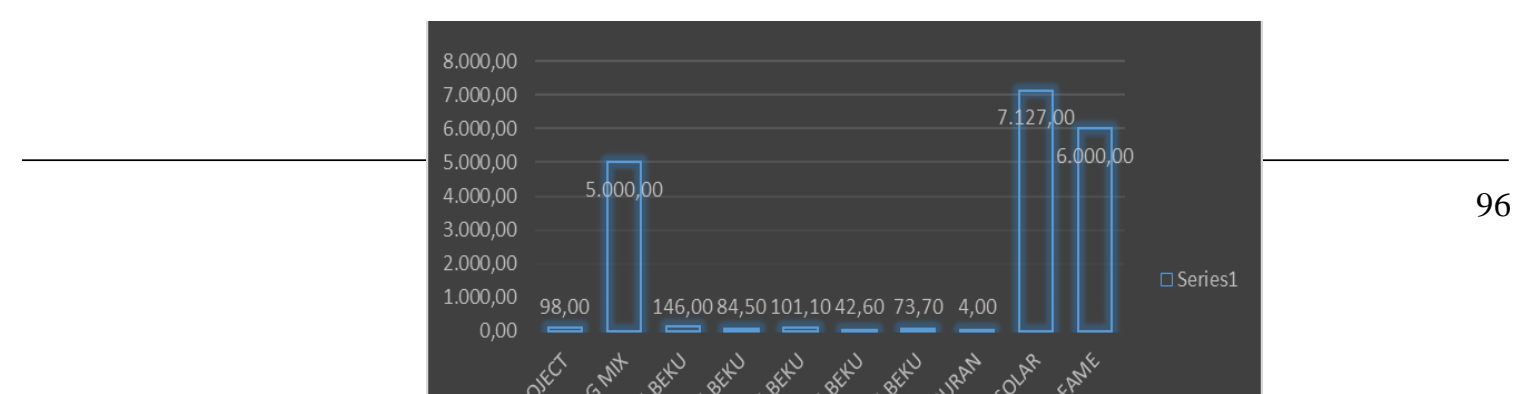


Gambar 2. Data Pembongkaran Muat (Sumber : Data Primer penelitian)

\section{Kesimpulan}

Berdasarkan pembahasan diatas, dapat disimpulkan bahwa di masa pandemi ini dapat dilihat degan jelas adanya penurunan pangan. Kekacauan perekonomian yang dikarenakan wabah Covid yang sampai saat ini belum berakhir membuat adanya pembatasan sosial bersekala besar di indonesia. Banyak dari pelabuhan yang menjadi faktor keterlambatanya pengiriman barang dari pelabuhan asal menuju pelabhan yang di tuju. Program tol laut dapat di kembangan pada pelabuhan Banyuwangi dikarenaan pelabuhan alam yang mempunyai kedalaman dan dermaga yang cukup luas bila adanya pembangunan di daerah tersebut. Supply cahin pada masa pandemi mengalami gangguan terutama pada pendistribusian barang di darat.

\section{Daftar Pustaka}

Abdy Kurniawan (2016), Desain Kapal Feeder Tol Laut Trayek T-5

Afandi, M. Z. (2013). Desain Konseptual Peti Kemas Untuk Alat Angkut Hewan Ternak Dari Kawasan Indonesia Timur Pada Kapal Penumpang 2 In 1. Surabaya: Institut Teknologi Sepuluh Nopember

Anjar Priyono (2008), Faktor Pendorong Dan Penghambat Rantai Pasokan Ramah Lingkungan : Literatur Review

Chandra Subiyantoro .(2017). Pengembangan Desain Peti Kemas Konvensional Menjadi Peti Kemas Lipat Khusus Untuk Alat Angkut Sapi

Elfrida R Gultom (2017), Merefungsi Pengangkutan Laut Indonesia Melalui Tol Laut Untuk Pembangunan Ekonomi Indonesia Timur

Hari Sucahyowati (2011), Manajemen Rantai Pasokan (Supply Chain Management)

Harry Boediarto.,(2017). Peluang Dan Tantangan Transportasi Laut Serta Logistik Maritime Di Nkri

Istopo, (1989), Kapal Dan Muatannya. Jakarta http://www.Bp3ipjakarta.Ac.Id/PenangananMuatan (10 Juni 2021)

Mohammad Hamzah Satriawansyah, (2016). Desain Kapal Penumpang Katamaran Untuk Rute Dermaga Boom Marina, Tanjung Wangi - Pelabuhan Benoa. 
Retno Muninggar.,(2018) Analisis Supply Chain Dalam Aktivitas Distribusi Di Pelabuhan Perikanan Nusantara Palabuhanratu (Ppnp)

Sugiyono. 2006. Metode Penelitian Kuantitatif Kualitatif dan R\&D. Bandung: Alfabeta. 